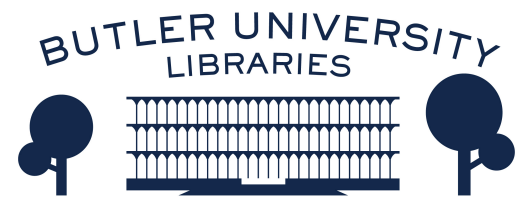

Journal of Hindu-Christian Studies

Volume 9

Article 18

January 1996

\title{
Book Review: "Rammohun Roy in Hindu and Christian Tradition: The Teape Lectures 1990"
}

Ronald Neufeldt

Follow this and additional works at: https://digitalcommons.butler.edu/jhcs

Part of the Religion Commons

\section{Recommended Citation}

Neufeldt, Ronald (1996) "Book Review: "Rammohun Roy in Hindu and Christian Tradition: The Teape Lectures 1990"," Journal of Hindu-Christian Studies: Vol. 9, Article 18.

Available at: https://doi.org/10.7825/2164-6279.1140

The Journal of Hindu-Christian Studies is a publication of the Society for Hindu-Christian Studies. The digital version is made available by Digital Commons @ Butler University. For questions about the Journal or the Society, please contact cbauman@butler.edu. For more information about Digital Commons @ Butler University, please contact digitalscholarship@butler.edu. 


\section{Rammohun Roy in Hindu and Christian Tradition: The Teape Lectures 1990. Dermot Killingley. Newcastle upon Tyne: Grevatt \& Grevatt, 1993, xii 181 pp.}

\section{RAMMOHUN ROY IN Hindu and} Christian Tradition is based on the Teape Lectures of 1990 , presented by the author at United Theological College in Bangalore, Bishop's College in Calcutta, and St Stephen's College in Delhi. Given the controversies Rammohun had with Trinitarians, it is appropriate that the Preface to this work is dated Trinity Week, 1993.

The author, Dermot Killingley, sets out to take aim at the various questionable images of Rammohun Roy which have, over time, become current in both Hindu and Christian estimates of the man and his contributions. Most are, he argues, projected images which need to be unpacked. Killingley's purpose in this volume is to do a bit of demythologizing, to strip away these projected images in order to come as close as is possible to the "real" Rammohun. To do this the author examines Rammohun's writings, both English and Bengali, devoting a considerable portion of the book to the responses to and writings on the Hindu and Christian traditions.

Among images and claims questioned by the author are claims that Rammohun Roy is the father of modern India, that he introduced modern Bengali prose singlehandedly and that he was the lone voice raised against the practice of sati. Certainly the author is correct to point out the exaggeration of these assessments, and to put Rammohun's contributions to modern India in some wider perspective. This is perhaps the most important contribution of the volume.

Important in this reassessment is the author's claim that Rammohun cultivated more than one persona in dealing with a variety of constituencies. For example, the claims made about Rammohun Roy by
Europeans have to be understood in terms of the persona he cultivated in his English writings. Of note is the fact that in his English writings Rammohun uses terms from rational theism rather than the concepts from Vedānta which appear in his Bengali writings. This language was construed by Europeans to mean that Rammohun was Unitarian or very close to conversion to Christianity. The point that the author makes convincingly throughout the book is that Rammohun Roy adopted modes of discourse to suit the audience. Although this point has been made in research on Rammohun Roy before, it is useful to see it support in the well-documented fashion presented in this volume.

The awareness of the various personae adopted by Rammohun Roy is important for Killingley's conclusion about Rammohun. Killingley states, "If we read his works carefully, they forbid us to regard him simply as a Hindu, a Christian, a Muslim or a rationalist" (p.160). Whether or not one agrees with this conclusion depends on the nuances one wishes to give to the word "simply". The awareness of the various personae adopted by Rammohun Roy notwithstanding, I would suggest that one can make a convincing case that Rammohun was Hindu, particularly once he begins to appeal to the authority of the Hindu texts for his religious positions. Such an argument can be seen even in his English writings. It is, of course, the case that in may respects Rammohun was not a traditionalist. But this would have to be said of many of the thinkers of so-called neo-Hinduism, who, like Rammohun, borrowed language and ideas which were in some respects foreign to traditional Hinduism.

These comments; however, do not detract in any way from the critical 
importance of this volume. It is an invaluable and well-documented source of information for anyone interested in Rammohun's controversies with Hindu traditionalists, Christians, and Unitarians, and therefore an important addition to research on interreligious dialogue in modern India. I is also one of the clearest expositions to date of the development of Rammohun's own thinking.

Ronald Neufeldt

Professor of Religious Studies

University of Calgary

\section{Die Symbolik von Gift und Nektar in der klassischen indischen Literatur. Ira Stubbe-Diarra. Wiesbaden: Harrassowitz Verlag (Studies in Oriental Religions, vol. 33), 1995, xii+154 pp.}

POISON (HALĀHALA, OR Kālakuta) and nectar (amrta) are the two ever recurring mythical beverages whose antagonistic symbolism in the Hindu religious world exceeds their mythological boundaries. This is the main thesis that Ira Stubbe-Diarra develops in her interesting and painstaking study. These drinks - the one deathprovoking and the other life-bringing, the unholy and the holy, the evil and the good have brought about numerous philosophical and hermeneutical discussions in the Hindu literature. After a brief reconstruction of the fundamental myth of the churning of the ocean (samudramathana) as found in several puranic and epic texts, Stubbe-Diarra presents the halähala-amrta symbolism through a rich analysis of numerous texts. This detailed and phenomenological enquiry covers all major purānas, the Rāmāyana and the Mahābhārata and some tantric texts.

Poison in Hindu mythology is seen not only as the deadly secretion which rose up and which was swallowed up by the serpents (naga) at the churning of the ocean, but also as the substance forming the strength of the warrior, fuelling in him anger and hate. It is .the wily energy of the witch as well as the enslaving power of ignorance and delusion. It can be neutralized or washed away and even harnessed only through higher divine agents like the bird Garuda, the sages, or through mantras and yogic powers.
Nectar brings not only life but life everlasting, immortality. Closely linked to the early vedic drink soma, it is further brought in relationship with the moon (soma), causing the principle of life to wax and wane. This force of life is seen also in the sun, in fire, in plants, and in water, notably in the Ganges, the heavenly flow of the primordial life-giving waters. The cow is full of nectar and imparts it to beings through her milk and urine. Life-giving semen too is nectar.

Stubbe-Diarra attempts an interpretation of these symbols (pp. 2, 142). According to her, Hinduism expresses through these symbols the dual conflicting forces of evil and good, death and life. However, these forces are not necessarily contradictory. Knowledge and a disciplined practice of yoga can overcome the deadly effects of poison and make it subservient to life (p.137).

We have here a handy work that makes available a variety of texts on the theme, accurately presented, bringing out deeper meanings of the symbols in question. The textual compilation is the strength of this work. Its weakness lies perhaps in the absence of an adequate methodology of interpretation. The mythical and the tantric expressions not being the same, they cannot be put on the same level of interpretation. The frequent quotations from English 